\title{
Chapter 2 \\ Legal Issues of Land Plots with Unknown Owners
}

\author{
Masaaki Iwasaki
}

\begin{abstract}
This paper describes how and why owner unknown lands have been increasing in Japan's shrinking population and proposes some ideas on the solution to the relating legal issues.
\end{abstract}

Keywords Real estate with unknown ownership - Administrative law · Tax law · Special measures act on vacant premises $\cdot$ Fixed assets tax $\cdot$ Inheritance tax

\subsection{Introduction}

\subsubsection{The Social Problem Created by Real Estate with Unknown Ownership (Vacant Premises and Abandoned Land)}

Real estate for which the owner cannot be immediately identified through owners' ledgers such as the register or for which contact cannot be made even if the owner has been identified is referred to as real estate with unknown ownership. Jurally, real estate with unknown ownership has two meanings: owner of building and owner of land are unknown in the above definition.

The specific details of 'unknown' cover various cases such as being unable to identify the current owner because the registered information in the various ledgers is old and out of date, where even if the owner can be identified, the owner's whereabouts is unknown (because the owner has moved or has a new address), there being multiple heirs following the death of the registered holder of the title deed and the registration of the transfer of ownership has not been possible due to not

\footnotetext{
M. Iwasaki $(\bowtie)$

School of Law, Meiji University, Tokyo, Japan

e-mail: iwasaki_m@meiji.ac.jp 
knowing about all of the heirs, and in the case like communal land (commonable iriai-chi (commonable land), etc.), where not all joint owners are listed in the owner's ledger. ${ }^{1}$

The various problems arising from such real estate with unknown ownership have existed for a long time. They have become evident at times of agrarian reforms, land readjustment projects, land redevelopment projects, etc. and whenever social problems emerged such as concerns about foreigners' buying up of water sources in mountainous regions.

Of particular note has been when there have been reconstruction projects that encouraged land redevelopment and migration following the Great East Japan Earthquake, real estate with unknown ownership attracted attention because it presented an obstacle for acquisition and reconstruction projects. ${ }^{2}$

The amount of real estate with unknown ownership tends to increase after the collapse of the bubble economy around the 1990s since real estate not directly used becomes 'negative' property because of maintenance and management costs due to the disillusion by the myth that land price continues to increase forever. According to calculations by 'The Working Group on the Problem of Land plots with unknown owners (Masuda Working Group)', the area of Land plots with unknown owners in Japan is reportedly even now to be on a par with the total area of Kyushu. ${ }^{3}$

\subsubsection{Problems in Terms of Administrative Law, Tax Law and Civil Transactions}

When undertaking various types of public works, surrender and use/expropriation in accordance with the Expropriation of Land Act become difficult if there is real estate with unknown ownership. Regarding small uncertified projects, it is difficult to process in accordance with the Expropriation of Land Act, so nothing can be done in the case of real estate with unknown ownership.

Collection of fixed assets tax and inheritance tax has been imperfect for real estate with economic value. Real estate that is only valued at below the tax exemption limit for fixed assets tax (mountain forests, wilderness, etc.) is neglected. There are also concerns that an heir of inherited property will neglect to register the inheritance,

\footnotetext{
${ }^{1}$ For examples of specific detail, see the Working Group on the Problem of Land plots with unknown owners (Chairman, Hiroya Masuda), 'Interim Report of the Working Group on the Problem of Land plots with unknown owners', dated June 2017 (hereinafter, the 'Interim Report'), p. 5-8.

${ }^{2}$ For case studies looking at the problem of real estate with unknown owners, see Shoko Yoshihara 'Land Issues in the Era of Depopulation' (Chuko Shinsho 2446) Chaps. 1, 2, 3, Tokyo Foundation for Policy Research (Shoko Yoshihara, Research Fellow), 'Shift towards Land plots with unknown owners-status of the problem indicated through survey of local governments' (Tokyo Foundation 2016) Survey Results.

${ }^{3}$ Interim Report, ibid (1) p. 17.
} 
which means preterition in the calculation of tax for inheritance tax; but this is not easily detected.

When there are redevelopment projects by private developers, matters cannot be processed with legal force, so real estate with unknown ownership becomes a major obstacle and can cause enormous economic loss.

\subsubsection{Enactment of the Special Measures Act on Vacant Premises}

'Act on Special Measures to Forward Municipalities' Moves for Vacant premises' (Act No. 127 of 2014), the so-called Special Measures Act on Vacant Premises, has been enacted and enforced in relation to property with unknown ownership, which finally draws a start to finding a resolution for real estate with unknown ownership. In this Act, property with unknown ownership is split into 'vacant premises, etc.' and 'designated vacant premises, etc.' according to the so-called level of risk, with corresponding measures.

Under this Act, vacant premises that have not been managed appropriately and have serious negative impact on local residents, such as related to disaster prevention, hygiene and presentation of the vacant premises, etc., are required to take measures to protect the life, body and property of local residents, to protect the living environment, to utilize the vacant premises, etc. (Article 1 of the Act). Note that the Act came into effect on February 26, 2015 (and May 26, 2105, for compulsory execution). According to studies undertaken in preparation of the establishment of this Act, there were estimated to be about 8.2 million vacant premises nationwide as of 2013. Four hundred one local governments have reportedly enacted ordinances for vacant premises as of October 2014 in response.

'Vacant premises, etc.' refer to 'buildings or structures incidental thereto that in their normal state are not used as residence or for other related purposes, and the sites thereof (including standing trees and other articles fixed to land)' (Article 2, paragraph (1) of the Act). The relevant measures for 'vacant premises, etc.' include promotion of appropriate management and administrative guidance and the valid use of administrative guidance including formulation of measures vis-à-vis the vacant premises by municipalities, a survey of the address and owner of vacant premises, etc., internal use of information for fixed assets tax and the preparation of a database of owner's information.

On the other hand, 'designated vacant premises, etc.' refer to vacant premises, etc. in (1) a situation where there is considerable concern about the danger in terms of security such as a collapse, (2) a situation where there is considerable concern about prospective harmful effects on health, (3) a situation where there has been considerable damage to the scenery due to the lack of appropriate management and (4) other inappropriate situations due to neglect in preserving the surrounding lifestyle environment (Article 2, paragraph (2) of the Act). In terms of measures to 
deal with 'designated vacant premises, etc.', the local government with jurisdiction is now able to take forcible actions such as onsite inspections, give advice, instructions, recommendations and orders to implement measures such as disposal, repair, felling of standing bamboo and trees, and demolition through administration by proxy (Article 14 of the Act).

These measures can be implemented where the owner of the vacant premises, etc., and the designated vacant premises, etc., has been identified. However, where the owner is unknown or uncontactable, it is not clear if it is possible to proceed in line with the hoped for purpose. In this regard, the Special Measures Act for Vacant premises is merely the starting line and not the goal for resolving property with unknown ownership.

\subsubsection{Discussion Concerning Measures to Deal with Land Plots with Unknown Owners Such as Abandoned Land}

By contrast, nothing has yet been legislated in relation to measures pertaining to Land plots with unknown owners such as abandoned land. Discussion is currently progressing at relevant administrative agencies, the Liberal Democratic Party, the government and private research associations.

First, as an initiative within the Ministry of Land, Infrastructure, Transport and Tourism initiatives, (1) Since April 2015, the 'Working Group on policies to deal with land for which the whereabouts of the owner is difficult to find (Akio Yamanome, chairperson)' has been investigating measures focused on promoting land expropriation and issued 'Guidelines for searching and utilizing land for which the whereabouts of the owner is difficult to find' in March 2016. The guidelines were further revised in March 2017 (Version 2). ${ }^{4}$

The National Land Council's Land Policy Committee also started to investigate the problem of Land plots with unknown owners, which led to the establishment of the 'Working Group on new uses for vacant land, etc. (Akio Yamanome, Chairperson)' in January 2017, which released a report in June that year. ${ }^{5}$ In addition, the Ministry of Justice investigated from October that year through the 'Working Group on Case Studies concerning the maintenance and management of jointly-owned private roads (Hiroshi Matsuo, chairperson)' and the 'Working Group concerning the approach to the titling system and land ownership (Akio Yamanome, Chairperson)'.

\footnotetext{
${ }^{4}$ Working Group on policies to deal with land for which the whereabouts of the owner is difficult to find, 'Guidelines for searching and utilizing land for which the whereabouts of the owner is difficult to find' (March 2017) www.mlit.go.jp/seisakutokatsu/iten/shoyusha.guideline.html.

${ }^{5}$ This can be found by searching on the following Ministry of Land, Infrastructure, Transport and Tourism website. www.mlit.go.jp/report/press/totikensangyo02_hh_000100.html.
} 
The next initiative by the government and the Liberal Democratic Party (LDP) was first the establishment of a Congressional Panel (Okiharu Yasuoka, Chairperson) within the LDP from October 2016 and a proposal that was put forward in April 2017. Subsequently, the 'Special Committee of the Policy Research Council of the LDP (Takeshi Noda, Chairperson)' commenced investigation that month from the perspective of promoting public works projects, with the release of an interim report dated June 1, 2017. The government also investigated from February 2017 through the Council on Economic and Fiscal Policy's Committee for Promoting the Integrated Economic and Fiscal Reforms (National and regional systems Working Group), etc. In response to these government and Liberal Democratic Party initiatives, the 'Basic Policies for Economic and Fiscal Management and Reform 2017: Investments for the Future Strategy 2017', or the so-called Basic Policies, were approved by the Cabinet on June 9, 2017, which incorporated measures that should be promoted to address Land plots with unknown owners.

Furthermore, in terms of private research associations, the 'Working Group on the Problem of Land plots with unknown owners (Hiroya Masuda, Chairperson)' was launched in January 2017, with an interim report released on June 26 of that year. Apart from this, the Japan Association for Real Estate Sciences, the Association of Urban Housing Sciences and the Japan Association for Property Assessment Policy jointly established the 'Working Group on Land plots with unknown owners (Masaaki Iwasaki, Chairperson)' in August that year, which is investigating such matters.

\subsection{Why Does Land Plots with Unknown Owners Arise?}

\subsubsection{The Potential Number of 'Unknown' Owners Is Very Large}

There are cases where the existence of the owner is unknown and cases where the owner has been identified, but the relationship of rights is unclear, and it is not possible to identify the true owner.

'The existence of the owner is unknown' includes not only an investigation of the owners' ledger such as the real estate register, but also when it is not possible to identify the whereabouts of the owner even having done a site survey.

'The relationship of rights is unclear' includes the situation where there has been a large increase in the number of heirs due to the passage of time during which the inheritance register has not been completed over a number of generations of heirs, so it has become unclear who has inherited what portion of land, and the situation where the land cannot be disposed of without agreement of all related parties as in the case of a community property or a common land. 
Since the potential number of such 'unknown' owners does not become evident until there is a need such as the sale of the land, the numbers can become quite large. ${ }^{6}$

\subsubsection{The Impact of Dilution of Family Relationships and Increase in Wastelands and Abandoned Land with Unknown Owners}

There are cases where even relatives have not had the opportunity to meet face to face, and even the relevant parties do not know their mutual legal relationship. Consequently, it becomes very difficult to progress the discussion about splitting inherited property. Furthermore, the relationship between relatives has been further diluted through successive divorces and remarriages, while confidentiality creates complications for inheritance. Since splitting inherited property is difficult, someone may continue to occupy the inherited land, yet to whom the land belong to may not be known.

The above changes in family relationships mean a likely increase in the number of cases where the owner is unknown.

\subsubsection{The Impact of Urban Concentration of Population and Industry: The Decline in Land Prices and Absence of Transactions in Regional Areas}

As for land with economic value, there may be people who want to acquire the ownership of such land even if there is the burden of taxes such as real estate registration tax levied at the time of inheritance, real estate acquisition tax and fixed assets tax.

However, few people want to acquire the ownership of land where the economic value does not cover the various costs and tax burdens associated with such inheritance.

The rate of real estate ownership on a household basis continued to increase during the high growth period from the mid-1960s, so on average more than $60 \%$ of households and about $80 \%$ of middle-aged and above households own real estate. ${ }^{7}$ In addition, there has been pronounced concentration of population and industry

\footnotetext{
${ }^{6}$ Interim Report. Ibid (1) pp. 10-17. See Yoshihara, Ibid (2) Chap. 2, The Tokyo Foundation for Policy Research, Ibid (2) pp. 9-25 for the results of the survey of local government entities.

${ }^{7}$ Statistical data can be retrieved from the Statistics Bureau, Ministry of Internal Affairs and Communications website. Current data is based on the 2013 survey. www.stat.go.jp/data/jyutaku/ 2013/10_3.htm.
} 
towards three major cities (Tokyo, Osaka and Nagoya) since the beginning of the Heisei era, at the end of the 1980s.

Therefore, subsequent generations of children and grandchildren work in the city, and if they own a residence there, they do not necessarily have a desire to acquire their parent's real estate in regional areas. In addition, there is a declining birth rates so there is also a decline in the number of persons in a position to take over the real estate of the parent's generation.

If the real estate can be sold, it could be sold after being registered on the ownership transfer register when inherited, but given the progress in urban concentration of population and industry, there are few land sales in regional areas. Therefore, the process of registration is neglected to avoid the burden such as the real estate registration tax, real estate acquisition tax, fixed assets tax, etc. that arise from ownership transfer. For example, there seem to be cases where heirs have agreed to exclude real estate from inherited property (i.e., also not register the transfer of ownership due to inheritance) to avoid inheritance tax. It is not easy to identify such properties that are excluded from inheritance as agreed to by heirs.

\subsubsection{Emergence of New Inheritance Problems: Real Estate Put in Storage Due to Elderly Inheritance and Inheritance Disputes}

Increased longevity means people are inheriting property at an increasingly older age. In the case of elderly inheritance, the heirs tend to neglect the inherited property due to a lack of desire, need and capacity to manage and maintain the inherited real estate. For example, even though the amendments to the Inheritance Tax Act allow for inheritance by grandchildren, the need for grandchildren to require real estate in regional areas that is not required by the parent's generation is not going to change, so this does not provide a fundamental solution.

On the other hand, claims to rights among heirs have intensified for real estate with economic value, so cases exist in which no progress has been made in terms of splitting inherited property. Selling inherited real estate to resolve the splitting of inherited property with disbursement of the proceeds resulted in taxation in the form of 'deemed capital gains' that was an impairment to such selling. So, partial amendments to legislation related to the enactment of the so-called Special Measures Act on Vacant Premises were implemented to prevent the capital gains tax from becoming unreasonable, and this mitigated such impairment a little.

That is, special measure for special tax exemptions on capital gains pertaining to vacant premises was established in accordance with the FY2016 tax system amendments as follows:

In the case of transfer of residential property between April 1, 2016, and December 31, 2019, by an heir or a person who acquires residential property through a bequest that (1) is the ancestor's residential property and the land that is provided 
to be used as the site thereof that is deemed to comply with certain requirements, or (2) the land that is used as the site following the disposal of such ancestor's residential property that is deemed to comply with certain requirements, apart from where the compensation for such transfer exceeds 100 million yen, the transfer costs pertaining to such transfer shall be subject to special exemption of 30 million yen in capital gains on the residential property (Article 35, paragraphs (3) through (10) of the Act on Special Measures concerning Taxation).

Although this is temporary legislation, it is expected to have an impact.

\subsection{Why Must the Issue of Land Plots with Unknown Owners Be Resolved?}

\subsubsection{Impact of Change in Family Relationships: Incomplete Management Due to Increase in One-Person Households Comprised of a Young or Elderly Person}

A trend in recent years has been in the increase in so-called one-person households comprised of younger generation or the elderly generation. People who live by themselves face a particularly heavy burden in maintaining and managing real estate.

There are fears that incomplete management of Land plots with unknown owners will cause concern for the health and security of nearby residents. In this regard, Land plots with unknown owners can no longer be called private property, and it has a strong sense of being public property in nature.

\subsubsection{Impairment on Public Works and Economic Activity}

Public works that are certified by legislation are projects necessary for public welfare. Even so, the inability to proceed is a major loss to the entire nation.

Public works for hazard prevention such as preventing major disasters caused by earthquakes, wind and flood damage, etc. have aspects that inevitably require forcible execution measures to deal with Land plots with unknown owners.

In addition, if regional improvements depend on national and regional public bodies, they tend to be delayed due to budget constraints. So there needs to be proactive promotion of redevelopment by private companies of Land plots with unknown owners that has economic value. On this point, it is useful to refer to the method of land banking used in the United States. ${ }^{8}$ That is, a system needs to be

\footnotetext{
${ }^{8}$ The 'Working Group on new uses for vacant land' also raised the issue about the need for a Japanese version of the land bank, and this is included in the matters for consideration in 'The Investments for the Future Strategy 2017', which was formulated by the government on the back of
} 
developed where corporations in which regional public organizations participate can acquire and hold land that is not being effectively utilized, with the relationship of rights clarified and the land leased or transferred to the private sector.

\subsubsection{Problem of Collecting Fixed Assets Tax, Inheritance and Gift Taxes Pertaining to Land Plots with Unknown Owners}

The owner listed in the register of lands and buildings or in the tax ledger as of January 1 each year is levied fixed assets tax as the taxpayer, even for Land plots with unknown owners. This tax notice is sent to the address of such taxpayer, but a considerable amount is returned as non-delivered mail. ${ }^{9}$

Fixed assets tax is a financial resource necessary for local administration, and it is also allocated towards the cost of maintaining order in the area under jurisdiction. Therefore, when collection of the fixed assets tax from the unknown owner remains impossible, it becomes a life-and-death problem for the regional public organization.

On the other hand, the owner who neglects the land is shifting the economic cost required for maintenance and management of such owner's estate to other residents, in the same way as being in receipt of excess profits.

One cannot shut one's eyes to the inability to collect fixed assets tax from the perspective of beneficiaries-pay principle of local taxes.

In the case of inheritance and gifts, if the ownership transfer is registered, such registered information is conveyed to the relevant Tax Office, with such information becoming tax documents for inheritance tax and gift tax. However, if the heirs and recipients arbitrarily neglect to register the ownership transfer from inheritance and gifts (registration is merely a requirement of perfection under the Civil Code and is also not an obligation), it becomes difficult to detect the fact of the inheritance or gift, making it easy to avoid paying tax.

the 'Basic Policies for Economic and Fiscal Management and Reform 2017 (Basic Policies 2017)', released on June 9, 2017. In terms of reporting on the American system, see Miho Maene, Yoko Shimizu and Toru Nakayama 'Research on business of vacant premise measures in the United States of America-About Flint, Michigan and Youngstown, Ohio', Reports of the City Planning Institute of Japan, No. 9, May 2010, pp. 27-30 and Yasuyuki Fujii 'The Detroit Land Bank Authority's Efforts to Cope with Vacant and Abandoned Properties in Targeted Neighborhoods', Journal of the City Planning Institute of Japan, Volume 50, No.3, 2015, pp. 1032-1038.

${ }^{9}$ See the Tokyo Foundation for Policy Research, Ibid above (2) pp. 9-25 for the survey results. 


\subsection{How Can the Problem of Land Plots with Unknown Owners Be Solved?}

\subsubsection{Policies to Deal with Land That Has Economic Value}

Land with economic value that is anticipated to be sold will be at a disadvantage unless the owner's name and address are registered regardless of whether it is inherited or a gift or an act caused by sale or other private law, so there is not much concern about the owner of such land being unknown.

Nevertheless, even for land with economic value, there is no great sense of need to register the name and address of the owner when that land is used for an intended purpose or for revenue, and even though there may be an occupant, the true owner may be unknown. In this case, it is possible to consider measures to resolve the problem caused by the owner being unknown through tax procedures and collection procedures. That is, first, measures should be considered that facilitate the compulsory collection of Land plots with unknown owners following the service of notice by publication as a procedure to deal with default on the payment of fixed assets tax if the tax notice for the fixed assets tax is dispatched and if non-delivery notices continue to be received for a certain period.

Second, if the person registered as the owner in the register or the tax ledger or the person who is registered is unknown, the provisions in Article 343, paragraph (2), latter clause of the Local Tax Act, should be revised to enable the collection of fixed assets tax from such land or building as the tax payer 'as the current owner', regardless of to whom it belongs.

According to the judgement of the Supreme Court dated July 17, 2015, strict investigation and identification of the ownership must be conducted even in this type of case, but this is forecast to be very difficult in practice. ${ }^{10}$

Third, there is a plan to make sure registered applications have a so-called common number and that registration of ownership transfer becomes an obligation with offenders levied with a fine. However, while measures to require registration of ownership transfer may have a certain level of effectiveness in preventing the omission of owned real estate, at the granular level, with only something like a fine, this does not appear to provide people who do not sense a need to register with incentive that forces them to register.

On the other hand, it may also be necessary to have incentive measures under the tax law that promote the transfer of ownership.

For example, as consistent with amendments to the system for deductions from income under the Income Tax Act, this could include the introduction of deductions of tax amounts with benefits together with the application of deductions on donations to promote donations of unneeded real estate to the government and public organizations. In this way, people with low incomes such as the elderly and

\footnotetext{
${ }^{10}$ Masaaki Iwasaki, 'Case Commentary' Jurist Special Edition 'Commentary on major cases for 2015’ (Jurist No. 1492), pp. 201-202.
} 
pensioners could benefit from a negative taxable income through the donation of unneeded real estate. This would increase the burden of land management cost of the national government, but would most likely substantially reduce the amount of Land plots with unknown owners.

\subsubsection{Measures to Deal with Land That Has Lost Its Economic Value}

For real estate that is valued below the tax exemption limit on fixed assets tax (the tax reference amount for the appraisal value is 300,000 yen for land and 200,000 yen for buildings: Article 351 of the Local Tax Act), the method for default procedures pertaining to fixed assets tax will not work. It is difficult to resolve the problem of Land plots with unknown owners with the above tax procedures and collection procedures.

Therefore, for land that has lost its economic value, the only way to transfer the control to the government or a public organization is to establish new forcible execution measures under administrative law. There is likely scope to establish a system that recognizes certified projects even if there is no plan for public works in order for the Expropriation of Land Act to apply.

On the other hand, in parallel with such compulsory measures, there should be measures to proactively promote the donation of land that is of public interest to the government or public organizations (land needed for transport, disaster prevention and public use). This would increase the land management fees for the government and public organizations, and that burden would ultimately need to be borne by citizens and residents through taxation. However, national property and property of public organizations are the property of citizens and residents, so it is only natural that they should bear the maintenance and management fee. This is much more logical than the current situation where the maintenance and management fee of private property that is Land plots with unknown owners is borne through tax revenues.

Note that even for the government and public organizations, approval of excessively large donations of unneeded and non-essential real estate would incur considerable cost and effort for its management that would eat into the budget, so some cases may be inappropriate for the national economy. As such, it might mean that real estate not needed for public purposes where the owner is not evident in places such as expansive mountain forests and wilderness areas may end up being neglected. Even if neglected, there is little concern of such land being acquired by foreign owners for example given the fact that the ownership is unknown. This suggests there is no near term danger, but whether or not it is right to neglect mountain forests and wilderness areas that have gone to ruin is a problem that should continue to be investigated as part of the overall approach to national land management. 
Open Access This chapter is licensed under the terms of the Creative Commons Attribution 4.0 International License (http://creativecommons.org/licenses/by/4.0/), which permits use, sharing, adaptation, distribution and reproduction in any medium or format, as long as you give appropriate credit to the original author(s) and the source, provide a link to the Creative Commons licence and indicate if changes were made.

The images or other third party material in this chapter are included in the chapter's Creative Commons licence, unless indicated otherwise in a credit line to the material. If material is not included in the chapter's Creative Commons licence and your intended use is not permitted by statutory regulation or exceeds the permitted use, you will need to obtain permission directly from the copyright holder. 